\title{
David Oliver: Let's end our fixation with structural reorganisation
}

\author{
David Oliver consultant in geriatrics and acute general medicine
}

Berkshire

From 2009 to 2013 I was on secondment to the Department of Health, as a clinical adviser and then a national clinical director, alongside my NHS day job. I had a ringside seat for the formation of the 2010 coalition government and the 2012 Health and Social Care Act, ${ }^{1}$ while also seeing its impact on the ground. After Andrew Lansley promised "no more top-down reorganisation," the changes his act introduced were described by David Nicholson, then chief executive of the NHS, as "so big, you could probably see them from space."3

The NHS in England is undergoing yet another mass restructuring- "redisorganisation," as analysts called it some years ago. ${ }^{4}$ It has a new 10 year plan. Last October the Nuffield Trust published a series of essays, Doomed to Repeat,${ }^{5}$ warning against making the same mistake of creating new organisational structures to "transform" or "reform" health services.

Since 2000 the NHS has had six national plans and 10 reorganisations: they've delivered few of the promised benefits, yet perhaps not all of the predicted harms. ${ }^{6}$ The 2012 act introduced several national leadership and regulatory bodies, removing or replacing others (notably, removing strategic health authorities and creating clinical commissioning groups). The complexity is outlined in a King's Fund animation, "How does the NHS in England work?"

Seven years on, where are we? Well, NHS England and NHS Improvement are set to work more closely together, if not quite merge, using more single leadership positions and closer collaboration in five co-located regional offices ${ }^{89}$ for just the kind of oversight that the (scrapped) strategic health authorities formerly gave.

It's all starting to look eerily close to the chain of command that Andrew Lansley scrapped back in 2012

NHS England is clearly the dominant party. Health Education England has become "accountable to NHS Improvement."10 NHS England is a statutory arm's length body but, as communications around the 10 year plan showed (with ministers taking credit), there are big, blurred lines between it and the department of state.
It's all starting to look eerily close to the chain of command that Lansley scrapped back in 2012, now dismantled. It would be nice to see some transparency, scrutiny, and open competition in appointments for new roles. We've had a terrible tendency to appoint the "usual suspects"-compounding the entrenched groupthink that redrawing the organogram will solve the NHS's wicked problems and exert central "grip."

Meanwhile, integrated care systems emerging from the 44 strategic transformation partnerships are being asked to deliver their own (one and 10 year) plans. These must contain all top-down elements of the national plan and are subject to financial control totals, so it's not clear how much local control there really is. Although not statutory entities, they're to be "accountable" for measures of population health. And now we have a requirement for GP networks covering populations of 30 000-50 000 — and much uncertainty about them among GPs. I'm an optimist who believes in the NHS and thinks that its national leadership is acting in good faith and making tough decisions. But I bet we'll be back at this crossroads in a few years, having forgotten-again-that structural reorganisation isn't the answer.

Competing interests: See www.bmj.com/about-bmj/freelance-contributors/davidoliver

Provenance and peer review: Commissioned; not externally peer reviewed.

Institute for Government. Never again? The story of the Health and Social Care Act 2012. 12 Jul 2012. https://www.instituteforgovernment.org.uk/publications/never-again.

2 Adams S. "No more top down reorganisations" muses NHS review group. Telegraph 26 Apr 2011. https://www.telegraph.co.uk/news/health/news/8474317/No-more-top-downreorganisations-muses-NHS-review-group.html.

3 Greer SL, Jarman H, Azorsky A. Centre for Health and the Public Interest. A reorganisation you can see from space: the architecture of power in the new NHS. Jan 2014. http:// citeseerx.ist.psu.edu/viewdoc/download?doi=10.1.1.698.9764\&rep=rep1\&type=pdf.

4 Smith J, Walshe K, Hunter DJ. The "redisorganisation" of the NHS. BMJ2001;323:1262-3. 10.1136/bmj.323.7324.1262 11731374

5 Nuffield Trust. Doomed to repeat? Lessons from the history of NHS reform. 16 Oct 2018. https://www.nuffieldtrust.org.uk/comment-series/doomed-to-repeat-it.

$6 \quad$ Ham C, Murray R. The NHS 10-year plan: how should the extra funding be spent? King's Fund. 12 Jul 2018. https://www.kingsfund.org.uk/publications/nhs-10-year-plan.

7 King's Fund. How does the NHS in England work? An alternative guide. 19 Oct 2017. https://www.youtube.com/watch?v=DEARD4l3xtE. 
8 NHS England. NHS England and NHS Improvement: working closer together. $27 \mathrm{Mar}$ 2018. https://www.england.nhs.uk/2018/03/nhs-england-and-nhs-improvement-workingcloser-together/.

9 NHS England. NHS England and NHS Improvement announce new senior leadership posts. 11 Dec 2018. https://www.england.nhs.uk/2018/12/nhs-england-and-nhsimprovement-announce-new-senior-leadership-posts/.
10 West D. HEE to become "accountable to NHS Improvement."Health Serv J 2018. https:/ /www.hsj.co.uk/policy-and-regulation/hee-to-become-accountable-to-nhs-improvement/ 7023642.article.

Published by the BMJ Publishing Group Limited. For permission to use (where not already granted under a licence) please go to http://group.bmj.com/group/rights-licensing/ permissions 